\section{Clay- and zeolite-based biogeosorbents: modelling and properties}

TATYANA N. SHCHEMELININA - Institute of Biology, Komi Science Center, Ural Branch of the Russian Academy of Sciences, Russian Federation - tatyanakomi@mail.ru

LÁszLó A. GÖMZE - Institute of Ceramics and Polymer Engineering, University of Miskolc - femgomze@uni-miskolc.hu

Olga B. KOTOVA - Institute of Geology, Komi Science Center, Ural Branch of the Russian Academy of Sciences, Russian Federation - kotova@geo.komisc.ru

JAMAL EldIN F. M. IBRAHIM - Institute of Ceramics and Polymer Engineering, University of Miskolc, Hungary • jamalfadoul@gmail.com

Dmıtry A. SHUSHKOV - Institute of Geology, Komi Science Center, Ural Branch of the Russian Academy of Sciences, Russian Federation - dashushkov@geo.komisc.ru

MARIA HARJA - "Gheorghe Asachi» Technical University of lasi, lasi, Romania • mharja@tuiasi.ro GrigorIY V. IGNATIEV - Institute of Geology, Komi Science Center, Ural Branch of the Russian Academy of Sciences, Russian Federation - ignatiev.grigoriy@gmail.com

Elena M. ANCHUGOVA - Institute of Biology, Komi Science Center, Ural Branch of the Russian Academy of Sciences, Russian Federation • urosova@gmail.com

Érkezett: 2019. 06. 26. " Received: 26. 06. 2019. " https://doi.org/10.14382/epitoanyag-jsbcm.2019.23

\section{Abstract}

This work presents data on the mineral and chemical composition of zeolite-containing and clay rocks considered as carriers for oil-oxidizing microorganisms, as well as their textural characteristics. The authors proved the use of mineral sorbents based on clay and zeolitecontaining rocks for design of a biogeosorption material of destructive type. The minerals met the requirements for oil sorbents (environmental compatibility, oil capacity, feasibility), and were biocompatible with Biotrin consortium. Hydrocarbon-oxidizing microorganisms combined with mineral sorbents had a significant destructive potential. The degradation of petroleum hydrocarbons by biogeosorbents modeled on 551, 541-31, 539-40 samples were 77, 60 and $65.5 \%$ for 4 days, respectively.

Keywords: biogeosorbents, clays, zeolites, Biotrin, petroleum hydrocarbons, $n$-alkanes, biodegradation, sorption

Kulcsszavak: biogeoszorbensek, agyagok, zeolitok, Biotrin, ásványolaj-szénhidrogének, n-alkánok, biodegradáció, szorpció

\section{Introduction}

Today, zeolite and zeolite-alumina composites, based on zeolite and clay rocks, are used in a wide area of industry and everyday life primarily as sorbents because of their technical, chemical, biological and medical properties. Water and soil pollution with hydrocarbons during exploration, mining, transportation, storage and processing should be noted to remain a significant environmental problem.

Many oil sorbents [1-8] are known to be divided into inorganic, natural organic and organic-mineral, and synthetic. Sorbents are evaluated mainly by their capacity to hydrocarbon pollutant under static conditions, the degree of hydrophobicity, the potentials for desorption, regeneration or utilization of the sorbent. Of course, the availability of raw materials and their cost must not be forgotten. Inorganic both sorbing and filtering materials include various types of clays, diatomite rocks, sand, zeolites, tuffs, pumice, etc. The methods for regenerating sorbents are processing with extractants or surfactants and burning, which causes secondary environment pollution [9].

The experience of the authors [10-13] shows that decontamination techniques using sorbents, biopreparations
Tatyana N. SHCHEMELININA

Senior researcher at the laboratory of biochemistry and biotechnology Institute of Biology, Komi Science Center, Ural Branch of the Russian Academy of Sciences. Her research is published in 1 book, more than 80 scientific articles, 23 patents. Member of the society of Biotechnologists.

László A. GÖMZE is establisher and professor of the Department of Ceramics and Silicate Engineering in the University of Miskolc, Hungary. He is author or co-author of 2 patents, 6 books and more than 300 scientific papers.

Olga В. KOTOVA

is professor and Head of Laboratory of Technology of Mineral Raw, Institute of Geology, Komi Science Center, Ural Branch of the Russian Academy of Sciences. Author and co-author of 4 patents and more than 150 scientific articles. Vice-president of International Commission on Applied Mineralogy (IMA-ICAM).Member of Russian Mineralogical Society.

Jamal Eldin F. M. IBRAHIM is a lecturer in the University of Bahri, Khartoum, Sudan, he graduated from University of Marmara, Istanbul, Turkey, Institute of Pure and Applied

Sciences, Department of Metallurgical and Materials Engineering, for the time being, he is a PhD student in the University of Miskolc, Institute of Polymer and Ceramics Engineering, under supervision of Prof. L. A. Gömze.

Dmitry A. SHUSHKOV Researcher of Laboratory of Technology of Mineral Raw, Institute of Geology, Komi Science Center, Ural Branch of the Russian Academy of Sciences. Author and co-author of 2 patents and more than 40 scientific articles. Russian Mineralogical Society.

Maria HARJA

isanassociate professor in Department of Chemical Engineering at "Gheorghe Asachi" Technical University of lasi, Romania.She is author or co-author of over 160 scientific papers (59 ISI) and 17 books.

Grigoriy V. IGNATIEV

JuniorresearcherofLaboratoryofChemistryofMineralRaw, Institute of Geology. Komi Science Center, Ural Branch of the Russian Academy of Sciences. He actually continues his studies as PhD student.

Elena M. ANCHUGOVA

Research engineer at the laboratory of biochemistry and biotechnology Institute of Biology, Komi Science Center, Ural Branch of the Russian Academy of Sciences. Author and co-author of 10 patents and more than 50 scientific articles. Member of the society of Biotechnologists

and zeolite and clay based biogeosorbents, which correlate with similar studies of zeolite and zeolite-alumina composites [14-16] are economically and environmentally desirable. Biopreparations composed of viable cells of microorganisms able to degrade hydrocarbon pollutants set the new trend in these studies. Such microorganisms are characterized by different physiological and biochemical properties, such as thermotolerance, osmophilicity, optimal $\mathrm{pH}$ for growth, capability of metabolize different classes of hydrocarbons. 


\begin{tabular}{lccc} 
Sample No & \multicolumn{1}{c}{ Rock } & Description & Deposit/occurrence \\
$\mathbf{5 5 1}$ & Analcime-containing & Brownish-gray argillite & "Veslyana", Koinskaya zeolite area \\
\hline $\mathbf{5 4 1 - 3 1}$ & Clinoptilolite-containing clay & Dark gray clay & Chim-Loptyuga oil shale deposit, Yarenga oil shale region \\
\hline $\mathbf{5 3 9 - 4 0}$ & Glauconite-containing & Green calcareous clay & Chim-Loptyuga oil shale deposit, Yarenga oil shale region \\
\hline $\begin{array}{r}\text { Table 1 } \\
\text { 1. táblázat }\end{array}$ & Collection of zeolite-containing and clay rocks for use as mineral carriers of oil degrading microorganisms
\end{tabular}

The production of biopreparations involves several disadvantages of freeze drying. Firstly, the supernatant fluid, containing pool of extracellular enzymatic activities, is removed, and secondly, the freeze drying may cause death of the most of the microorganisms. Thirdly, not all associations of microorganisms can restore destructive activity after freezing exposure, which eliminates the feasibility of the use of many biological products in winter [17].

The production of biogeosorbents based on mineral raw materials solves problems both of increasing efficiency of microorganism cell immobilization, preserving their viability and biochemical activity by replacing freeze drying with the immobilization of microorganisms with a sorbent, and utilization of sorbent materials. In environmentally unfavorable conditions, sorbents act as a transport base for microorganisms, which allows up to 10 years anabiosis. Another advantage, compared with biopreparations, is the economic efficiency associated with a decrease in the amount of biogeosorbent used in the process of bioremediation $[8,18]$.

High ion-exchange and sorption capacities of clay and zeolites result in their wide use in environmental protection: to purify drinking water and industrial effluents, to regenerate soil, to remove harmful gases from industrial emissions [19-24]. The ability of clays and zeolites to absorb and retain water allows effectively immobilizing microorganisms and their metabolites on the surface. The sorption binding of hydrocarbons reduces toxicity of the environment to the microorganisms and fixes the substrate in close proximity to the microbial community. As a result, this raw material is a mineral fertilizer; it is not necessary to utilize the biogeosorbent [25].

To describe the interaction of oil and clay particles in aquatic microcosms, Lee et al. [26] suggested the term oilmineral aggregates (OMA) and identified three types of the aggregates: droplet, solid, and flake aggregates. Droplet aggregates are represented by the smallest oil droplets surrounded by individual mineral particles or their floccules. In solid aggregates, oil and mineral bodies of various shape up to tens of micrometers are mixed. Flake aggregates are ordered thin sheets and can reach the millimeter size range. Solid oil-mineral aggregates, formed in microcosms with the participation of clays and zeolites, attach to minerals, which increases their size [27].

The aim of the work is to model biogeosorbents based on clay and zeolite rocks and Biotrin biopreparation, to study their sorption and oil degrading properties.

\section{Objects and methods of research}

The objects of study were:

1. Zeolite-containing and clay rocks of the European Northeast of Russia (Table 1).
2. Strains of microorganisms in the composition of Biotrin biopreparation [28]:

- bacteria Pseudomonas yamanorum VKM B-3033D, isolated from highly contaminated soil of the railway bed in the area of Syktyvkar [29];

- yeast Rhodotorula glutinis, VKM Y-2998D [30];

- microalgae Chlorella vulgaris Beijer. f. globosa V. Andr. IPPAS C-2024.

\subsection{Biogeosorbent Modeling}

The biomass of bacteria was cultivated meat-peptone broth: per $1 \mathrm{dm}^{3}$ of tap water: peptone $-20 \mathrm{~g}, \mathrm{NaCl}-3.0 \mathrm{~g} ; \mathrm{KCl}-$ $1.0 \mathrm{~g} ; \mathrm{MgSO}_{4} \times 7 \mathrm{H}_{2} \mathrm{O}-0.5 \mathrm{~g}$ at a temperature of $15-25{ }^{\circ} \mathrm{C}$ for 3-5 days of liquid phase fermentation process.

Yeast biomass was cultivated on the Čapek medium: per $1 \mathrm{dm}^{3}$ of water: sucrose $-20 \mathrm{~g}, \mathrm{NaNO}_{3}-5.0 \mathrm{~g}$; $\mathrm{KH}_{2} \mathrm{PO}_{4}-1.0$ g; $\mathrm{KCl}-0.5 \mathrm{~g} ; \mathrm{MgSO}_{4} \times 7 \mathrm{H}_{2} \mathrm{O}-0.5 \mathrm{~g}$, at a temperature of $15-25^{\circ} \mathrm{C}$ for 5 days of liquid phase fermentation process.

Microalgae biomass was cultivated on the Tamiya medium: per $1 \mathrm{dm}^{3}$ of water: $\mathrm{KNO}_{3}-5.0 \mathrm{~g}$; $\mathrm{FeSO}_{4} \times 7 \mathrm{H}_{2} \mathrm{O}-0.003 \mathrm{~g}$; $\mathrm{MgSO}_{4} \times 7 \mathrm{H}_{2} \mathrm{O}-2.5 \mathrm{~g} ; \mathrm{KH}_{2} \mathrm{PO}_{4}-1.25 \mathrm{~g}$, at a temperature of $15-25^{\circ} \mathrm{C}$ for 10 days of liquid phase fermentation process.

The suspensions obtained were combined into Biotrin biopreparation. The biogeosorbents were produced by application of Biotrin biopreparation (cell titer $10^{9}$ ) directly to the mineral carriers with a particle size of $0.1-0.25 \mathrm{~mm}$ in the ratio of 1 part of the biopreparation to 6 parts of the sorbent.

\subsection{Preparation of oil polluted water (model water sample)}

$0.5 \mathrm{~g}$ of oil was added to $100 \mathrm{~cm}^{3}$ of Czapek's medium without sucrose. It was aerated in a shaker at $180 \mathrm{rpm}$ for 4 days at room temperature and natural light. The water was filtered. The total petroleum hydrocarbon (TPH) content in the reference sample was $0.121 \mathrm{ppm}$, which was 2.4 times higher than the standards of maximum permissible concentrations in the water of fishery reservoirs in Russia [31].

\subsection{Experimental design}

Prepared water polluted with oil was poured into $250 \mathrm{~cm}^{3}$ flasks and $1 \mathrm{~g}$ of initial sorbents and biogeosorbents based on them were added. The experiment was carried out for 4 days at room temperature, natural light, aeration in a shaker (180 $\mathrm{rpm})$.

$\mathrm{TPH}$ in the model water sample, in the oil-mineral aggregates formed was analyzed fluorimetrically using Fluorat-02 liquid analyzer [32].

The qualitative and quantitative determination of the content of $n$-alkanes was carried out by Trace DSQ (Thermo) chromatomass spectrometer in the mode of selective ion detection (SIM) at an electron energy $70 \mathrm{eV}$. SIM scanning was carried 
out in three ions with masses 57, 71 and 85, characteristic of saturated hydrocarbons. $\mathrm{N}$-alkanes in the chromatogram were identified previously in the mode of the full ion current using their standard solutions. The quantitative content of $n$-alkanes was studied by the internal standard method (the internal standard - $n$-decane, $0.05 \mathrm{mg} / \mathrm{cm}^{3}$ ) [33].

\section{Results and discussion}

The mineral and chemical compositions of the initial mineral carriers are previously published by Shchemelinina et al. [34].

Cultured strains of microorganisms were immobilized on the sorbents, and their surface was studied using a scanning electron microscope. As seen in Fig. 1, there are clusters of Biotrin microorganisms, fixed on the surface of mineral carriers.

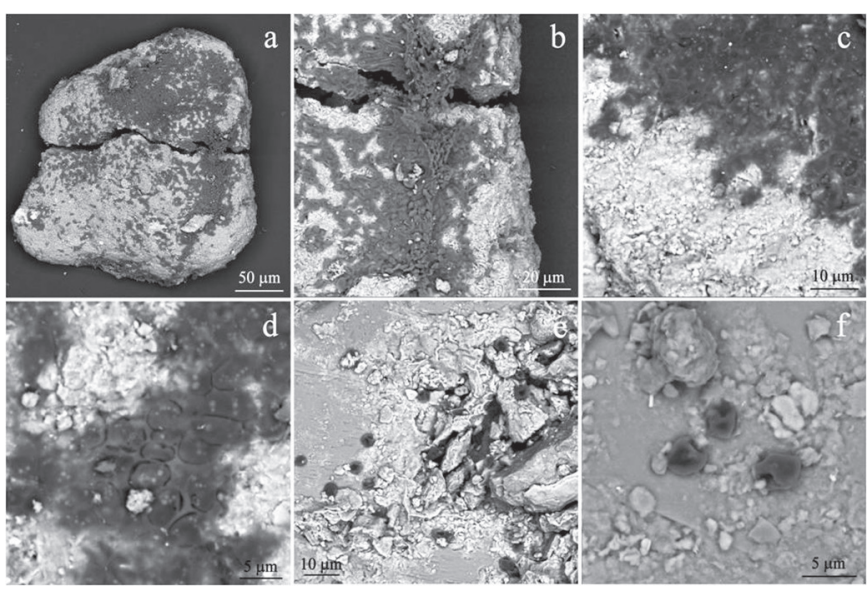

Fig. 1 SEM images of the surface of mineral carriers (light) with immobilized oil degrading organisms (dark) in the mode of backscattered electrons: $a-d-R$. glutinis yeasts, $e-f$-C. vulgaris $\mathrm{f}$. globosa microalgae

1. ábra SEM képek az immobilizált ásványok (világos) valamint olaijal roncsolt organizmusok (sötét) felületéröl visszaszórt elektronok módszerével: $a-d-R$. glutinis élesztö, $e-f$ - C. vulgaris $\mathrm{f}$. globosa microalga

The sorption was evaluated in relation to TPH of the initial sorbents and biogeosorbents modeled. Earlier researches pointed out analcime-containing rock 551, clinoptilolitecontaining clay 541-31, and glauconite-containing rock 53940 as the most promising as sorbents and carriers for Biotrin biopreparation.

The analysis of the water in the microcosms after application of both analcime-containing rock 551, and biogeosorbent based on it confirms the reliable high water purification levels, but variations in treatments with sorbent/biogeorbent are insignificant, and important differences are noted in sample 551. Samples of clinoptilolite-containing clay 541-31 and biogeosorbent based on it showed the efficiency of TPH reduction. Significant differences in $\mathrm{TPH}$ content in both water and OMAs of 539-40 glauconite-containing sample are observed (Table 2).

\begin{tabular}{lcc} 
Sample & TPH content in water, ppm & TPH content in OMA, mg/g \\
$\mathbf{5 5 1}$ & $\frac{0.111 \pm 0.015}{0.044 \pm 0.005}$ & $\frac{57 \pm 9}{250 \pm 30}$ \\
\hline $\mathbf{5 4 1 - 3 1}$ & $\frac{0.058 \pm 0.008}{0.035 \pm 0.004}$ & $\frac{100 \pm 16}{250 \pm 30}$ \\
\hline $\mathbf{5 3 9 - 4 0}$ & $\underline{0.072 \pm 0.009}$ & $\frac{20 \pm 3}{58 \pm 9}$ \\
\hline Reference sample & $0.024 \pm 0.003$ & - \\
\hline
\end{tabular}

Table 2 TPH content in the microcosms when the initial sorbents and biogeosorbents based on them applied

Note: in the numerator - biogeosorbent applied, in the denominator - sorbent applied. The indicated values did not exceed $1 \%$ variance for TPH.

2. táblázat Az elemi térfogatokban a TPH-tartalom jelentkezése szorbensek és biogeoszorbensek alkalmazása esetén

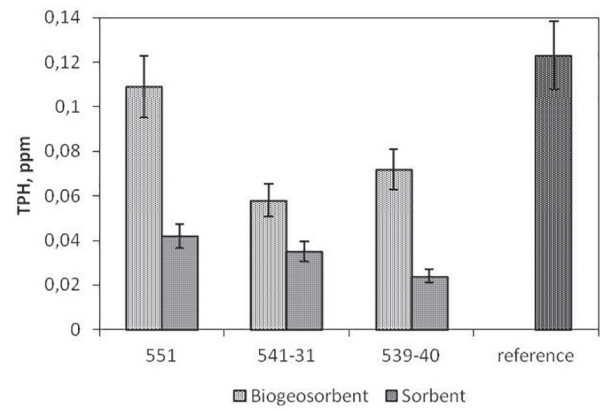

Fig. 2 TPH content in water samples when applying various sorbents and biogeosorbents based on them

2. ábra A TPH-tartalom a vízmintákban különbözö szorbensek és biogeoszorbensek alkalmazása esetén

The experiment showed (Fig. 2) that the initial samples of these sorbents exhibited adsorption activity with respect to TPH. As a result of the application of these samples into oil-contaminated water, the content of pollutant in water decreases in 4 days by 63,71 and $80 \%$ for samples 551, 541-31, 539-40, respectively. When the biogeosorbents based on clay and zeolite-containing rocks are applied into polluted water, water purification efficiency decreases $(8,52,40 \%$, respectively), which indicates a decrease in the sorption properties of mineral carriers after immobilization of microorganism cells. The decrease in the sorption properties of the biogeosorbents is probably caused by decreasing specific surface because of adhesively fixed biomass of microorganisms. This is confirmed by experimental data on the specific surface area of sorbents and biogeosorbents (Table 3). In almost all the cases, the specific surface area of the raw sorbents is higher than the specific surface area of the biogeosorbents. When microorganisms are immobilized on the sorbents, the specific surface area decreases by 1.01-8.75 times.

The hydrocarbon biodegradation in samples 551, 541-31, $539-40$ is 77,60 and $65.5 \%$ for 4 days, respectively (Table 2).

\begin{tabular}{ccc}
$\begin{array}{c}\text { Sample } \\
\text { No. }\end{array}$ & \multicolumn{2}{c}{ Specific surface area, $\mathbf{~ m}^{2} / \mathrm{g}$} \\
without degassing & with degassing at $\mathbf{2 5}{ }^{\circ} \mathrm{C}, \mathbf{2}$ hours \\
\hline $\mathbf{5 5 1}$ & $\frac{13.65}{13.79}$ & $\frac{8.24}{16.67}$ \\
\hline $\mathbf{5 4 1 - 3 1}$ & $\frac{8.56}{10.60}$ & $\frac{11.32}{10.03}$ \\
\hline $\mathbf{5 3 9 - 4 0}$ & 2.17 & $\frac{2.72}{23.80}$ \\
\hline
\end{tabular}

Table 3 Specific surface area of sorbents and biogeosorbents Note: in the numerator - biogeosorbent, in the denominator - sorbent.

3. táblázat A szorbensek és a biogeoszorbensek fajlagos felülete 
We identified C16-C33n-alkanes in the water samples studied (Table 4).

\begin{tabular}{lcc} 
Sample & $\begin{array}{c}\Sigma C_{16-33} \\
\mu \mathrm{g} / \mathrm{dm}^{3}\end{array}$ & $\frac{\Sigma C 16-23}{\Sigma C 24-36}$ \\
$\mathbf{5 5 1}$ & $\frac{5.54}{6.55}$ & $\frac{0.22}{0.42}$ \\
\hline $\mathbf{5 4 1 - 3 1}$ & $\frac{2.28}{2.36}$ & $\frac{0.15}{0.29}$ \\
\hline $\mathbf{5 3 9 - 4 0}$ & $\frac{0.7}{8.97}$ & 0 \\
\hline Reference & 13.53 & 0.23 \\
\hline
\end{tabular}

Table 4 Alkanes in oil-contaminated water after application of sorbents and biogeosorbents

Note: in the numerator - biogeosorbent, in the denominator - sorbent

4. táblázat Alkanák olajos vízben szorbensek és biogeoszorbensek alkalmazása után

The major part of normal alkanes covers the homological series in the range C16 to C33 with maxima of C29 and C31. Odd alkanes in the range of C25, C27, C29, C31, C33 prevailed. The ratio of light $(\Sigma \mathrm{C} \leq 23)$ to heavy molecules $(\Sigma \mathrm{C}>23)$ is 0.52 (Table 4, Fig. 3).

When sorbents applied, the qualitative and quantitative distribution of alkanes is significantly different in oilcontaminated water. After analcime-containing rock 551 application (Table 4, Fig. 3A), the alkane content decreased 2.1 times compared with the reference. Mass concentrations of C28 and C30 prevailed over all other individual compounds. Light $(\Sigma \mathrm{C} \leq 23)$ to heavy molecules $(\Sigma \mathrm{C}>23)$ ratio was 0.42 . When the biogeosorbent applied, no important differences were observed in the total content of $n$-alkanes, while light to heavy molecules ratio was 1.9 times lower, and the ranked homological series are dominated by hydrocarbons with the numbers of carbon atoms C27, C29, and C31.

Application of sorbent and biogeosorbent based on clinoptilolite-containing clay 541-31 reduces the amount of $n$-alkanes by more than 5 times (Table 4, Fig. 3B), but the differences within the variants are not significant. The distribution curve of the mass concentrations of alkanes in water after applying of biogeosorbent became identical to the curve after applying of sorbent.

The bulk of alkanes in water after processing with glauconitecontaining rock 539-40 is represented by C17 - C33 homologues and amounts to $8.97 \mu \mathrm{g} / \mathrm{dm}^{3}$ (Table 4, Fig. 3C), reduced by $34 \%$ relative to the reference with a reliable concentration of $\mathrm{C} 27$, C29, C31 homologues in the microcosm. Due to the low mass concentrations of homologs, the identification of patterns of distribution is difficult.
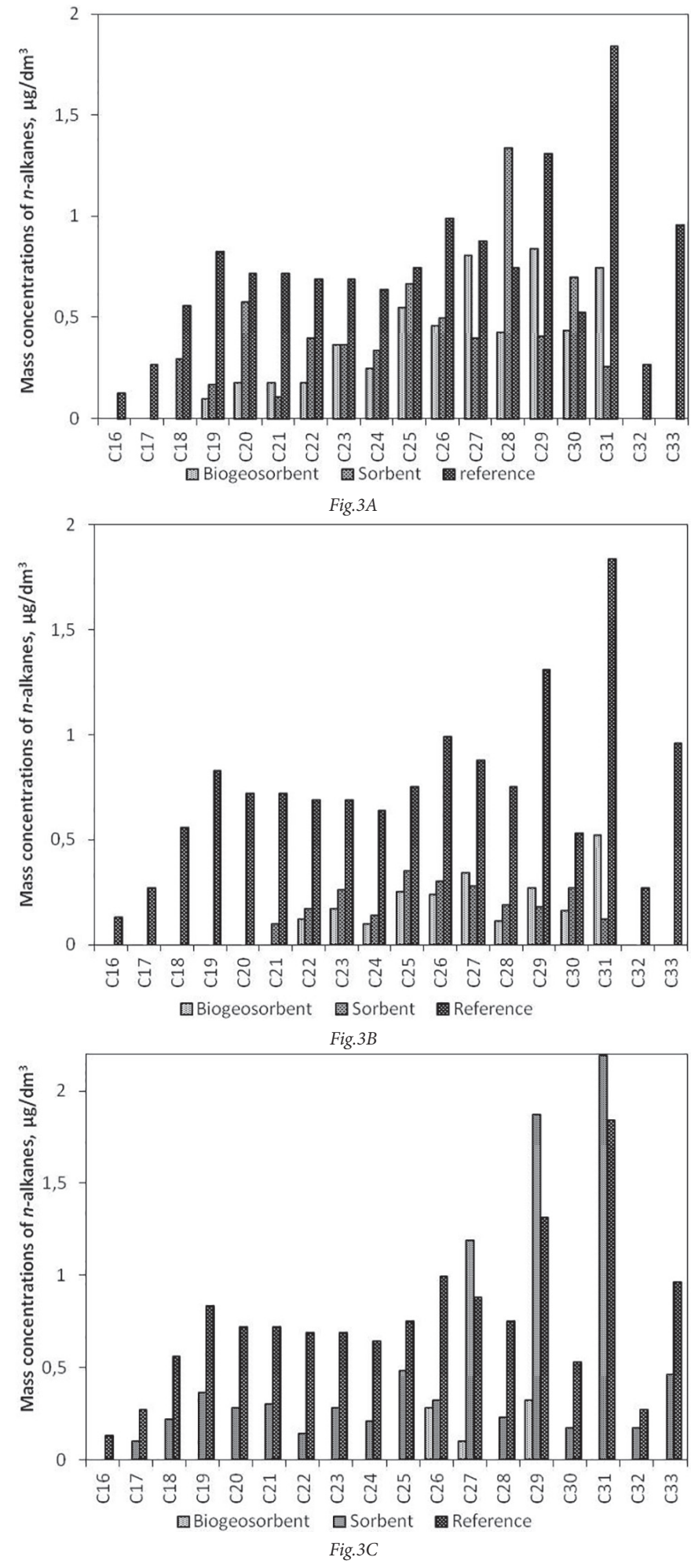
Fig. 3 Distribution of mass concentrations $\left(\mu \mathrm{g} / \mathrm{dm}^{3}\right)$ of alkanes in the aqueous samples. A - after application sorbent 551 and biogeosorbent based on it; $B$ - after application sorbent 541-31 and biogeosorbent based on it; $C$ - after application sorbent 539-40 and biogeosorbent based on it
3. ábra Az alkánok tömegkoncentrációjának $\left(\mu \mathrm{g} / \mathrm{dm}^{3}\right)$ megoszlása a vizes mintákban. A - 551 szorbenssel és biogeoszorbenssel kezelve; $B$ - 541-31-es szorbenssel és biogeoszorbenssel kezelve; C - 539-40-es szorbenssel és biogeoszorbenssel kezelve

Our experiments confirm the data obtained by Netzer et al. [35] that the formation of aggregates contributed to $\mathrm{TPH}$ removal from the water because of accumulation and 
biodegradation. Solid oil-mineral aggregates can be attached to minerals, which increase their size [27]. It was noted (Fig. 4) that TPH accumulation in the aggregates formed by biogeosorbents was significantly lower (by 77, 60, 66\% for biogeosorbents modeled on 551, 541-31, 539-40 samples, respectively) than in the aggregates based on the minerals studied, which is most likely related to the biodegradation of hydrocarbons accumulated by the cells of Biotrin consortium.

In OMA sample of the analcime-containing rock 551 (Table 5, Fig. 5A), we identified C16-C32 n-alkanes, the total content was $11.84 \mu \mathrm{g} / \mathrm{g}$, the proportion of light alkanes in the composition was 2.33. C17, C18 homologues dominated. The data indicate that the sample is capable of holding light alkanes, which under natural conditions undergo weathering processes. In OMA of 551B, the amount of alkanes is threefold decreased (3.89 $\mu \mathrm{g} / \mathrm{g}), \mathrm{C} 19-\mathrm{C} 31$ compounds were identified without a clear predominance of any homologs. The light $(\Sigma \mathrm{C} \leq 23)$ to heavy molecules $(\Sigma \mathrm{C}>23)$ ratio was 0.57 .

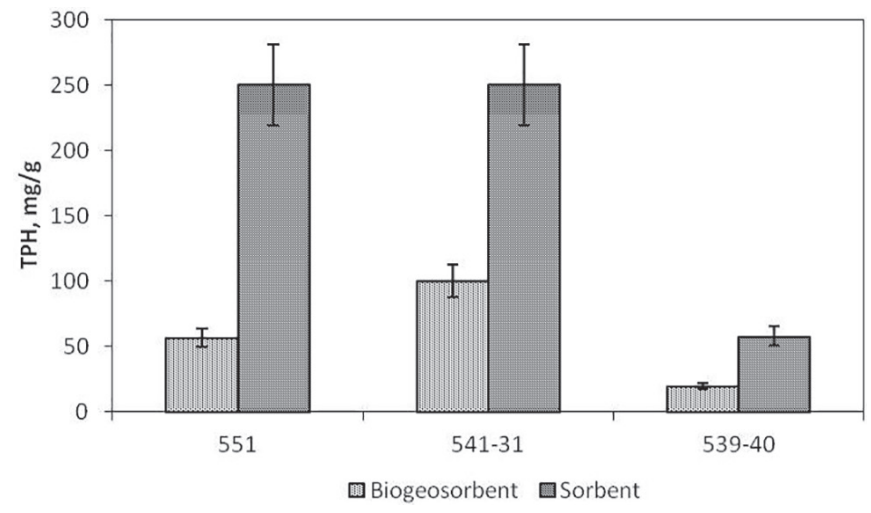

Fig. 4 TPH content in OMA

4. ábra TPH-tartalom az OMA-ban

The decrease in the $n$-alkane content in the water of the microcosm was also accompanied by the accumulation in OMAs [26, 36, 37]. Different homolog sequences were identified in the samples.

\begin{tabular}{|c|c|c|}
\hline Sample & $\begin{array}{l}\Sigma C_{16-32} \\
\mu g / d^{3}\end{array}$ & $\frac{\Sigma C 16-23}{\Sigma C 24-32}$ \\
\hline 551 & $\frac{3.89}{11.84}$ & $\frac{0.57}{2.23}$ \\
\hline 541-31 & $\frac{5.14}{8.84}$ & $\frac{0.34}{1.14}$ \\
\hline $539-40$ & $\frac{9.11}{8.28}$ & $\frac{0.19}{0.31}$ \\
\hline
\end{tabular}

Table 5 Alkanes in oil-polluted water after the use of sorbents and biosorbents Note: in the numerator - biogeosorbent, in the denominator - sorbent 5. táblázat Alkánok olajjal szennyezett vízben szorbensek és biosorbensek használata után.

The major part of normal alkanes in the OMA sample based on clinoptilolite-containing clay 541-31 covers the homological series in the range of $\mathrm{C} 16$ - $\mathrm{C} 30$, the mass concentrations of C17, C19 prevail over other individual compounds. The light $(\Sigma \mathrm{C} \leq 23)$ to heavy $(\Sigma \mathrm{C}>23)$ ratio was 1.14 (Table 5). In OMA of the biogeosorbent, the amount of alkanes is lower by $42 \%$ and amounted to $5.14 \mu \mathrm{g} / \mathrm{g}$, the pert of light alkanes is 0.34 . Fig. $5 B$ shows that the distribution of alkanes C $>23$ in OMA of the sorbent and the biogeosorbent is identical.
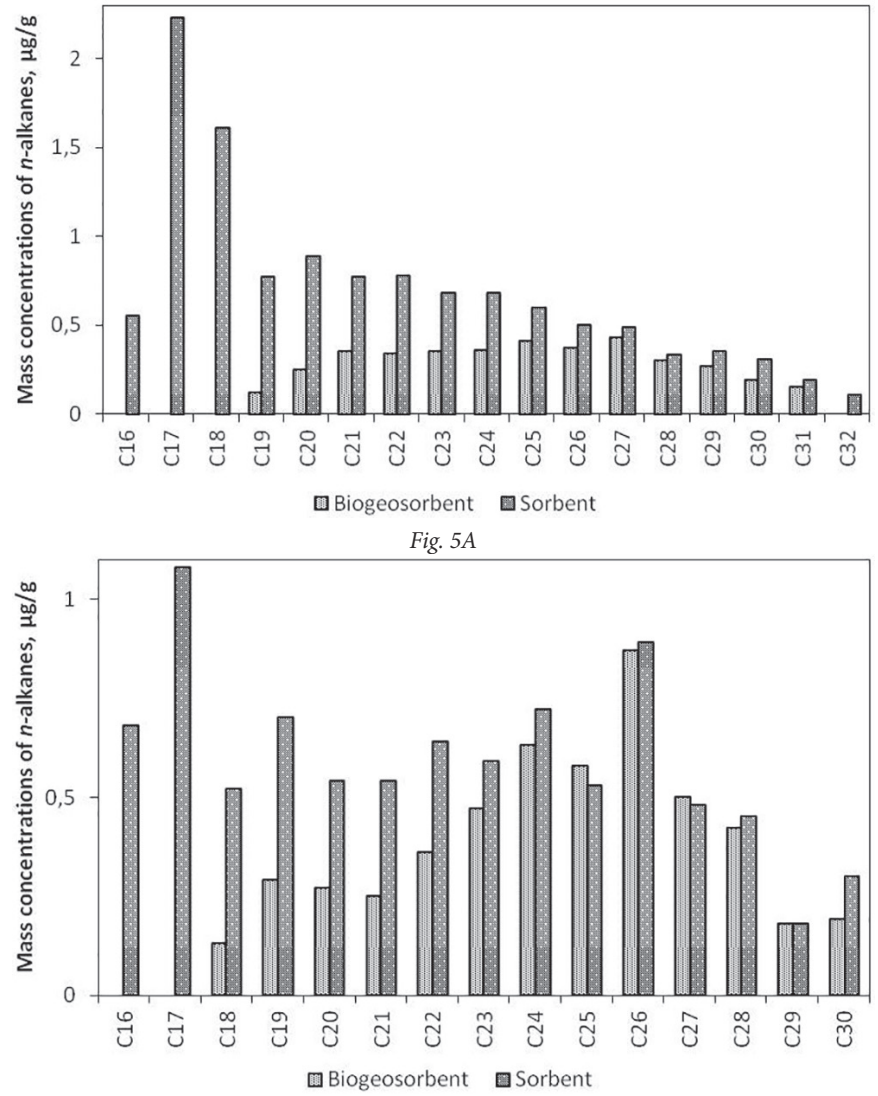

Fig. 5B

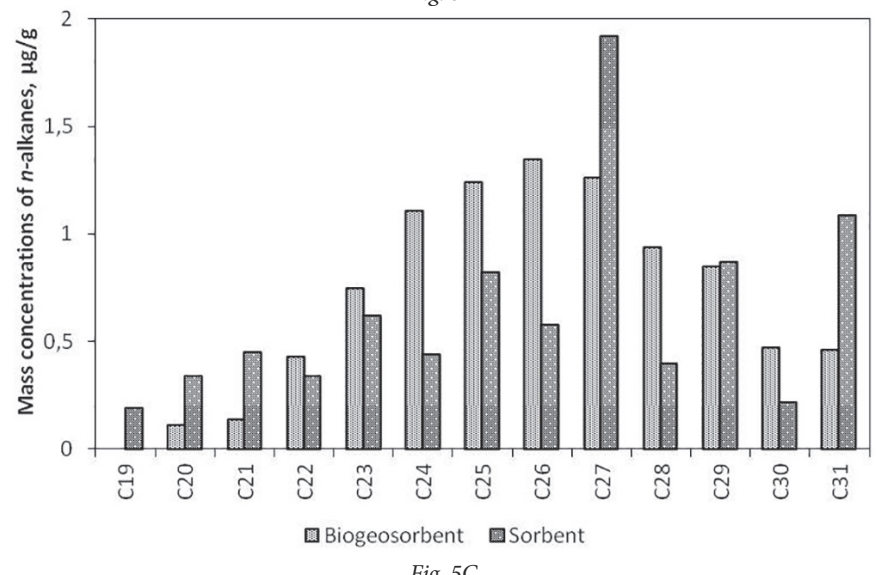

Fig. 5C

In OMA of sorbent and biogeosorbent of glauconitecontaining rock 539-40, C19 - C31 n-alkanes were identified, there were no significant differences in the total content of alkanes (8.28 and $9.11 \mu \mathrm{g} / \mathrm{g}$, respectively (Table 5)). However, the distribution pattern of individual compounds is different (Fig. 5C): OMA of the biogeosorbent accumulates C24-C28 compounds, while C27 homologue prevails in OMA of the sorbent.

Thus, the course of the process of biodegradation of hydrocarbons can be traced quite clearly by the distribution 
of alkanes in OMAs. The ratio of normal alkanes changes, lighter alkanes degrade more quickly. The predominance of odd chains occurs when alkanes are formed in the microcosms as a result of microbiological transformation of organic matter [37]. The dominance of odd long-chain homologues of alkanes indicates that both oil and biomass characterized by a similar type of $n$-alkanes spectrum are the main sources in OMAs of biogeosorbents [39]. Probably, microorganisms convert them into the corresponding fatty acids, followed by incorporation directly into cellular lipids.

\section{Conclusion}

Our experiments resulted in modelling of biogeosorbents, in which clay and zeolitic rocks of the European Northeast of Russia are carriers for oil-oxidizing microorganisms of Biotrin biopreparation immobilized on them. Among the samples studied, the most promising as a sorbent and carrier of Biotrin biopreparation are analcime-containing rock 551, clinoptilolite-containing clay 541-31, and glauconitecontaining rock 539-40. Samples of the initial sorbents show high adsorption of hydrocarbons.

During the immobilization of microorganism cells on the surface of mineral carriers, we revealed decreasing sorption properties, but at the same time, the microorganisms supported the oxidation of hydrocarbons. The TPH biodegradation in the biogeosorbents modeled on 551, 541-31, 539-40 samples for 4 days is 77,60 and $65.5 \%$, respectively. The analcime-containing rock 551, clinoptilolite-containing clay 541-31 are capable of holding volatile low molecular weight alkanes.

\section{Acknowledgements}

The authors are grateful to the Center for Collective Use Geoscience and the eco-analytical laboratory of the Institute of Biology of Komi SC UB RAS for their help with the analytical work, as well as to I.N. Burtsev for providing samples of clinoptilolite-containing and glauconite-containing rocks.

The work was partly supported by the State Task No. AAAA-A17-117121270025-1 "Development of biocatalytic systems based on enzymes, microorganisms and plant cells, their immobilized forms and associations for processing plant raw, obtaining biologically active substances, biofuels, remediation of polluted soils and wastewater treatment» and No. AAAA-A17-117121270037-4 «Scientific basis for effective subsoil use, development and exploration of the mineral resource base, development and implementation of innovative technologies, geological and economic zoning of Timan-North Urals region».

\section{References}

[1] Demina, L. A. How to wash «Black Gold» (2011): On the elimination of oil pollution. Energiya (Energy). No. 10, pp. 51-54. (In Russian)

[2] Al-Jammal, N. - Juzsakova, T. (2016): Review on the effectiveness of adsorbent materials in oil spills clean up. $7^{\text {th }}$ International Conference of ICEEE. Budapest, Hungary. pp. 131-138.

[3] Al-Jammal, N. - Juzsakova, T. - Zsirka, B. - Sebestyén, V. - Németn, J. Cretescu, I. - Halmágyi, T. - Domokos, E. - Rédey, Á. (2019): Modified Jordanian zeolitic tuff in hydrocarbon removal from surface water. Journal of Environmental Management. Vol. 239, pp. 333-341. http://doi.org/10.1016/j.jenvman.2019.03.079
[4] Adebajo, M. O. - Frost, R. L. - Kloprogge, J. T. - Carmody, O. - Kokot S. (2003): Porous materials for oil spills cleanup: a review of synthesis and absorbing properties. Journal of porous materials. Vol. 10, Is. 3, pp. 159170. http://doi.org/10.1023/A:1027484117065

[5] Worthington, M. J. H. - Shearer, C. J. - Esdaile, L. J. - Campbell, J. A. - Gibson, C. T. - Legg, S. K. - Yin, Y. - Lundquist, N. A. - Gascooke, J. R. - Albuquerque, I. S. - Shapter, J. G. - Andersson, G. G. - Lewis, D. A. Bernardes, G. J. L. - Chalker, J. M. (2018): Sustainable polysulfides for oil spill remediation: repurposing industrial waste for environmental benefit. Advanced Sustainable Systems. Vol. 2, Is. 6. http://doi.org/10.1002/adsu.201800024

[6] Alekseeva, T. P. - Burmistrova, T. I. - Trunova, N. M. - Naumova, L. B. - Shilyaeva, L. P. (2017): Evaluation of the use of zeolite to accelerate the destruction of oil in the soil // Biotechnologiya (Biotechnology). 2017. Vol. 33, No. 4, pp. 85-91. (In Russian)

[7] Sulimenko, L. P. - Koshkina, L. B. - Masloboev, V. A. (2017): Practical aspects of the use of sorbents for the rehabilitation of local oil-polluted northern territories. Vestnik of the Kola Scientific Center of RAS. No. 1, pp. 116-123. (In Russian)

[8] Shchemelinina, T. N. - Kotova, O. B. - Anchugova, E. M. - Shushkov, D. A. - Ignatiev, G. V. (2018): Zeolite and clay raw materials: experimental modeling of biogeosorbents. Vestnik of Institute of Geology of Komi SC of UB of RAS. No. 9, pp. 50-57. (In Russian)

http://doi.org/10.19110/2221-1381-2018-9-50-57

[9] Artyukh, E. A. - Mazur, A. S. - Ukraintseva, T. V. - Kostyuk, L. V. (2014): Prospects for the use of biosorbents for cleaning water bodies in the event of oil spill response. Izvestia of SPb MTI (TU). No. 26, pp. 58-66. (In Russian)

[10] Harja, M. - Kotova, O. - Ciobanu, G. - Litu, L. (2017): New adsorbent materials on the base of ash and lime for lead removal. Proceedings book: International Symposium "The environment and the industry". SIMI 2017, Bucharest, Romania. http://doi.org/10.21698/simi.2017.0009

[11] Kotova, O. - Shmakova, A. - Ponaryadov, A. (2017): Scientific basis for creation of construction materials based on titanium and alumina minerals. IOP Conf. Series: Materials Science and Engineering. Vol. 175, 012002. http://doi.org/10.1088/1757-899X/175/1/012002

[12] Shmakova, A. - Kanev, B. - Gömze, L. A. - Kotova, O. (2017): Crystal chemical characteristics and physical properties of ferrous minerals as the basis for the formation of functional materials. IOP Conf. Series: Materials Science and Engineering. Vol. 175, 012015. http://doi.org/10.1088/1757-899X/175/1/012015

[13] Kotova, O. B. - Maskalchuk, L. N. - Shushkov, D. A. - Leontieva, T. G. Baklai, A. A. (2017): Radionuclide sorbents based on industrial wastes: physical and chemical properties and application potential // Vestnik of Institute of Geology of Komi SC of UB of RAS. No 4, pp. 29-36. http://doi.org/10.19110/2221-1381-2017-4-29-36

[14] Buzimov, A. Y. - Eckl, W. - Gömze, L. A. - Kocserha, I. - Kurovics, E. - Kulkov, A. S., Kulkov, S. N. (2018): Effect of mechanical treatment on properties of Si-Al-O zeolites. Építőanyag-Journal of Silicate Based \& Composite Materials. Vol. 70, No. 1, pp. 23-26. http://doi.org/10.14382/epitoanyag-jsbcm.2018.2

[15] Gömze, L. A. - Kulkov, S. N. - Kurovics, E. - Buyakov, A. S. - Buyakova, S. R. - Buzimov, A. Y. - Géber, R. - Grigoriev, M. V. - Kocserha, I. - Kulkov, A. S. - Sablina, T. Yu. - Savchenko, N. L. - Sevostyanova, I. N. - Simon, A. (2018): Investigation of mineralogical composition and technological properties of conventional brick clays. Építöanyag-Journal of Silicate Based \& Composite Materials. Vol. 70, No. 1, pp. 8-12. http://doi.org/10.14382/epitoanyag-jsbcm.2018.2

[16] Gömze, L. A. - Kurovics, E. (2018): Influence of compacting times and pressures on rheological properties of alumina and quartz ceramic powder mixtures. Journal of Physics: Conference Series. Vol. 1045, 012011. http://doi.org/10.1088/1742-6596/1045/1/012011

[17] Review of the market of oil sorbents in Russia. InfoMine. Research team. Report 2008. 142 p. Access mode: http://www.infomine.ru/ research/18/300/ (In Russian)

[18] Shchemelinina, T. N. - Kotova, O. B. - Harja, M. - Anchugova, E. M. - Pelovski, Y. - Cretescu, I. (2017): New trends in the mechanisms of 
increasing productivity of mineral-based materials. Vestnik of Institute of Geology of Komi SC of UB of RAS. No 6, pp. 36-38.

http://doi.org/10.19110/2221-1381-2017-6-40-42

[19] Krajňák, A. - Viglašova, E. - Galamboš, M. - Krivosudsky, L. (2018): Kinetics, thermodynamics and isotherm parameters of uranium (VI) adsorption on natural and HDTMA-intercalated bentonite and zeolite. Desalination and Water Treatment. Vol. 127, pp. 272-281. http://doi.org/10.5004/dwt.2018.22762

[20] Semenkova, A. S. - Romanchuk, A. Yu. - Krupskaya, V. V. - Pokidko, B. V. - Dorzhieva, O. V. - Sobolev, A. V. - Presnyakov, I. A. - Verma, P. K. Mohapatra, P. K. - Kalmykov, S. N. (2018): Np(V) uptake by various clays. Applied Geochemistry. Vol. 92, pp. 1-8. http://doi.org/10.1016/j.apgeochem.2018.02.006

[21] Delkash, M. - Bakhshayesh, B.E. - Kazemian, H. (2015): Using adsorbents to clean up special wastewater streams: A review. Microporous and Mesoporous Materials. Vol. 214, pp. 224-241. http://doi.org/10.1016/j.micromeso.2015.04.039

[22] Steffin, J. E. - Dilson, B. S. - Manikandan, P. M. (2016): An overview on activated carbon and zeolites in water treatment. Imperial Journal of Interdisciplinary Research. Vol. 2, Iss. 11, pp. 6-11.

[23] Ziyath, A. M. - Mahbub, P. - Gooonetilleke, A. - Adebajp, M. O. - Kokot, S. - Oloyede, A. (2011): Influence of physical and chemical parameters on the treatment of heavy metals in polluted stormwater using zeolite - a review. Journal of Water Resource and Protection. Vol. 3, pp. 758-767. http://doi.org/10.4236/jwarp.2011.310086

[24] Shushkov, D. A. - Shuktomova, I. I. - Rachkova, N. G. - Harja, M. (2018): Porosity and sorption properties of zeolites synthesized from coal fly ash // Vestnik of Institute of Geology of Komi SC of UB of RAS. No 3, pp. 32-37. http://doi.org/10.19110/2221-1381-2018-3-32-37

[25] Levchenko, M. L., Gubaidullina, A. M. (2009): Glauconitic sands for environmental protection and restoration of the natural properties of soils and the aquatic environment. Ecologiya I Progress. Burenie I Neft (Ecology and Progress. Drilling and Oil). No. 4, pp. 56-57. (In Russian)

[26] Lee, K. (2002): Oil-particle interactions in aquatic environments: Influence on the transport, fate, effect and remediation of oil spills. Spill Science \& Technology Bulletin. Vol. 8, pp. 3-8. http://doi.org/10.1016/S1353-2561(03)00006-9

[27] Chen, L. - Zhou, Y. - Wang, X. - Zwicker, T. - Lu, J. (2013): Enhanced oilmineral aggregation with modified bentonite. Water Science \& Technology. Vol. 67, No. 7, pp.1581 - 1589. http://doi.org/10.2166/wst.2013.013

[28] Conclusion about toxicological and hygienic assessment of Biotrin consortium of oil-oxidizing microorganism strains. SIC TBP branch «State Research Center Institute of Immunology». Serpukhov, 28.09.2017. (In Russian)

[29] RU Patent 2615458 Bacterial strain Pseudomonas yamanorum VKM B-3033D to enhance the biodegradation of petroleum and petroleum products in water, as well as in oil soils on railway sections / BIOEKOBALANS LLC; S. M. Meskelo, T. N. Schemelinina, E. M. Anchugova, M. Yu. Markarova, S. V. Zheludkova. Stated 10/08/2016; Publ. 04.04.2017 Byul. No. 10. (In Russian)

[30] RU Patent 2658134 The strain of the yeast Rhodotorula glutinis for the purification of oil-contaminated soils, water bodies and wastewater from petroleum hydrocarbons, including for the oxidation of polyaromatic compounds / BIOEKOBALANS LLC; S. M. Meskelo, T. N. Schemelinina,
M. Yu. Markarova, E. M. Anchugova. Stated 07/02/2016; Publ. 06/20/2018 Byul. No. 17. (In Russian)

[31] Order of the Ministry of Agriculture of the Russian Federation of December 13, 2016 No. 552. On approval of water quality standards for water bodies of fisheries significance, including standards for maximum allowable concentrations of harmful substances in waters of water bodies of fisheries importance. (In Russian)

[32] Methods for measuring the mass fraction of petroleum products in soil samples by a fluid analyzer "Fluorat-02". Federal State Budgetary Institution of Science Institute of Biology, Komi Scientific Center, Ural Branch of the Russian Academy of Sciences. PND F 16.1.21-98. M., 1998. 15 p. (In Russian)

[33] Gabov, D. N. - Beznosikov, V. A. - Kondratenok, B. M. - Gruzdev, I. V. (2010): Saturated hydrocarbons in the background and polluted soils of the Pre-Urals. Eurasian Soil Science. No. 43, pp. 1002-1008. http://doi.org/10.1134/S1064229310100030

[34] Shemelinina, T. N. - Kotova, O. B. - Anchugova, E. M. - Shushkov, D. A. - Ignatiev, G. V. (2018): Zeolite and clay raw: experimental modeling of biogeosorbents. Vestnik of Institute of Geology of Komi SC of UB of RAS. No. 9, pp. 50-57. (In Russian) http://doi.org/10.19110/2221-1381-2018-9-50-57

[35] Netzer, R. - Henry, I. A. - Ribicic, D. - Wibberg, D. - Brönner, U. Brakstad O. G. (2018): Petroleum hydrocarbon and microbial community structure successions in marine oil-related aggregates associated with diatoms relevant for Arctic conditions. Marine Pollution Bulletin. Vol. 135, pp. 759-768. http://doi.org/10.1016/j.marpolbul.2018.07.074

[36] Gong, Y. - Zhao, X. - Cai, Z. - O’Reilly, S. E. - Hao, X. - Zhao, D. (2014): A review of oil, dispersed oil and sediment interactions in the aquatic environment: Influence on the fate, transport and remediation of oil spills. Marine Pollution Bulletin. Vol. 79, pp. 16-33. http://doi.org/10.1016/j.marpolbul.2013.12.024

[37] Payne, J. R. - Clayton, J. R. - Kirstein, B. E. (2003): Oil/suspended particulate material interactions and sedimentation. Spill Science \& Technology Bulletin. Vol. 8, pp. 201-221. http://doi.org/10.1016/S1353-2561(03)00048-3

[38] Gennadiev, A. N. - Zavgorodnyaya, Yu. A. - Pikovsky, Yu. I. - Smirnova, M. A. (2018): Alkanes as components of soil hydrocarbon status: behavior and indication significance // Eurasian Soil Science. No.1, pp. 32-41. http://doi.org/10.1134/S1064229318010076

[39] Roig, M. G. - Kennedy, J. F. - Knill, C. J. - Sanchez, J. M. - Pedraz, M. A. - Jerabkova, H. - Kralova, B. (2001): Kinetics of biodegradation of n-alkanes by Pseudomonas immobilized in reticulated polyurethane foam. Recent Advances in Environmentally Compatible Polymers. Cellucon '99 Proceedings. Ed. by J.F. Kennedy, G.O. Phillips, P.A. Williams. Great Britain: Abington Woodhead Publishing Limited, 2001. pp. 397-404.

Ref.:

Shchemelinina, Tatyana N. - Gömze, László A. - Kotova, Olga B. - Ibrahim, Jamal Eldin F. M. - Shushkov, Dmitry A. - Harja, Maria - Ignatiev, Grigoriy V. - Anchugova, Elena M.: Clay- and zeolite-based biogeosorbents: modelling and properties Építőanyag - Journal of Silicate Based and Composite Materials, Vol. 71, No. 4 (2019), 131-137. p. https://doi.org/10.14382/epitoanyag-jsbcm.2019.23

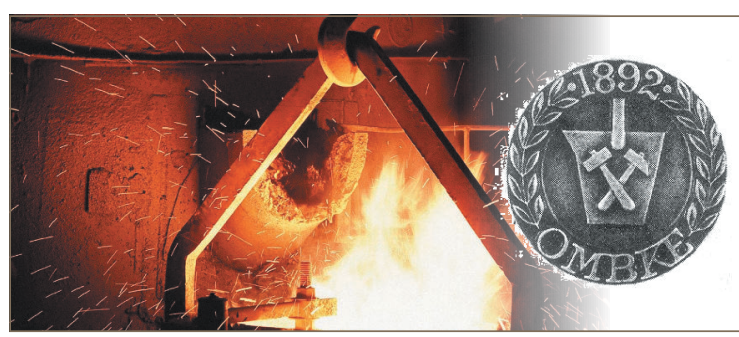

OMBKE

Országos Magyar Bányászati és Kohászati Egyesület Hungarian Mining and Metallurgical Society

www. ombkenet.hu 